\title{
THE TRANSFORMATION OF THE EUROPEAN PARLIAMENT
}

\author{
Juliet Lodge ${ }^{*}$
}

\begin{abstract}
What role should the European Parliament of the European Union assume in the post-Nice run-up to further enlargement? Should it continue catalysing system transformation by re-defining its obligations in the light of contemporary circumstances and needs? By exploiting existing rules and by setting out future visions, including blueprints for a constitution, MEPs are developing the EP as the custodian, conscience and guardian of the kind of liberal democratic values, norms and behaviour appropriate to the millennium and characteristic of western liberal democratic representative government. This paper looks at how this has occurred. It shows how the EP moved from being the federalising dynamo behind realising a democratic institutional balance to promoting a participatory democracy as the champion of the people. The paper divides into four sections: (i) examines the EP's transformation from assembly to co-legislature arguing that it perpetually seeks redefinition; (ii) relates this to a re-conceptualisation of democratic legitimacy; (iii) addresses normative issues and the linkage between the institutional and civil dimensions to democratic legitimacy; and (iv) outlines roles that might be both necessary and appropriate to a supranational legislature in the post-Nice treaty runup to the next wave of enlargement and crucially fundamental institutional reform to accommodate new member states.
\end{abstract}

*Juliet Lodge is Professor of European Integration and Jean Monnet Professor of European Union policy and Director of the Centre for European Studies, part of the Jean Monnet Centre of Excellence, University of Leeds (UK). Author of numerous books and articles, her research focuses on democratic legitimacy, CFSP and the internal and external security of the EU. 


\section{Background}

\subsection{The EP as a System Changer and Transformer}

No longer a consultative assembly, the EP has developed dramatically, notably since 1984. It continues to develop many of the organisational attributes and legislative, scrutiny and control functions common to member states' national parliaments. These are not yet fully developed. The EP therefore undergoes perpetual re-definition and transformation in impelling system change. It seeks :a defined role as the EU's legislature; greater authority and power to control the executive, shape and determine the legislative agenda and legislative outputs; greater democratic legitimacy; and a single seat. The fifth Euro-elections in June 1999 focused attention on what kind of a body it is now and aspires to be in the new millennium. ${ }^{1}$

While the elements of its mission remained fairly constant from the $1950 \mathrm{~s}$, the detail, balance and the relative priority between them fluctuated according to contemporary demands. Thus, for example, democratic legitimacy and direct elections assumed prominence before the EP genuinely increased its legislative power, and declined in importance during the 1980s. Then the focus switched to increasing the EP's legislative, scrutiny and control functions as the EP systematically exploited its treaty given powers, via a policy of small steps combined with the qualitative leap initiatives associated with Spinelli and Martin, inter alia.

By the end of the 1990s, the EP exercised co-legislative functions as part of a bi-cameral legislature with the Council of Ministers. Formally changing the EP-Council balance of power remains contentious but less emotive, in terms of national sovereignty, than ten years ago. That is not the same thing as saying that the balance of power between the EP and member governments is less problematic. If anything, the Commission's resignation in March 1999 made it more problematic, but paradoxically more amenable to resolution than before because the EP highlighted the fact that the member states were key, but not supreme, actors within the supranational system.

Political circumstances during the lifecycle of the fourth elected EP heightened determination to transform the EP's capacity to act more like 
national parliaments on major issues of the day. After Maastricht, few thought that newly elected MEPs would want to redefine the EP's role, let alone those of the EU itself. But MEPs put system-change at the top of the EU's political agenda shortly before the start of a 1999 Euro-election campaign that had threatened to be dull and unlikely to mobilise public interest. Tribulations over control and oversight of the European Central Bank, EMU and the euro coupled with ratification and implementation of the Amsterdam treaty(TEA) (with its serious implications for political accountability, especially under pillar III), EU enlargement before agreement had been reached at the Nice IGC on crucial institutional reforms, concern over financial irregularities and mismanagement, and the seemingly directionless Commission eventually highlighted in the public eye the need for the EP to exercise effective parliamentary scrutiny and authority over EU policy processes which eluded national control. This coincided with growing awareness that these policy processes - misleadingly depicted as the outcome of bureaucratic/technocratic decisionmaking - were supremely political. As such appropriate political control was vital. Within hours of the Commission resigning in March 1999, the EP's ability to play a continuing system transformative role came to be recognised. The process of redefining a role for itself in preparation for enlargement was therefore further highlighted.

\subsection{The EP : Re-defining Subsidiarity and Parliaments' role in Good Government}

The EP has come of age as a legitimate EU institution with a desirable role. It questions, shapes and suggests appropriate modes of political interaction for the EU and member states. Until the Commission's resignation, the idea of redefining and refining subsidiarity was not seriously contemplated. Subsidiarity is not merely about curbing supranational institutions' intervention and ambition, but also about ensuring that national and sub-national political institutions contribute to the democratic well-being of their local and the evolving supranational polity : they are the implicit guardians of good government within their domain.

If subsidiarity reflected a contest and national jealousy over the exercise of power, it would have been logical to engage in a territorial and then vertical distribution of power and competence, as is typically found in 
federal polities of the western liberal democratic kind. To some extent the TEU and TEA did this but from the time of the 1990 'assizes' convened by the EP with national MPs, the idea of a non-hierarchical relationship between co-equal supranational and national legislatures was developed. It was assumed that effective functioning and communication between the EP and national parliaments was needed to ensure that government (at both levels) was open and democratically accountable. Recognition of the need for common/joint action to combat the threat to parliamentary functions and powers at both levels supplanted old ideas of rivalry between them. Similarly, the introduction of the Committee of the Regions confirmed the idea that representative, subnational assemblies also had a role to play in promoting good, democratic government as close to the people as possible. Again, the old idea that this institution too should be seen in a competitive sense as a threat to the national sovereignty of national parliaments gave way to two evolutionary models. The first rested on it having a strictly defined and limited remit; the second on it adding value to the task of maintaining democratic accountability, primarily by the EP (with whom it still has to develop effective links) and by national and local governments.

Subsidiarity needs re-definition as an aid to promoting sustainable supranational government. On the one hand is the issue of a vertical, hierarchical distribution of authority at whose apex stand the national governments; on the other, that of distributive politics - appropriate task definition and resourcing in an enlarging EU: how, why and by whom policy priorities are set. Accordingly, member governments must publicly acknowledge the Commission's political/quasi-governmental role, thereby redefining their relationship with it, and between the Commission and other EU institutions. By implicitly accepting MEPs' views (clear upon the investiture of the Santer Commission, and re-asserted upon Prodi's investiture) that the Commission needs to be led by a credible, strong politician with a sense of mission and vision, governments recognise their altered and changing position in EU governance and responsibility for ensuring that EU policymaking (not merely in a functional technocratic sense) has politically legitimated priorities, and appropriate resources to attain and sustain goals. In that sense, they stop being 'rivals to' and become 'partners' of the Commission - and the EP - in a common game. The EP's role extends now beyond legitimising others' policy proposals and agendas to include it in the very process of defining and implementing that agenda. at role regard cannot cease when the EP invests the incoming Commission. 


\subsection{The EP : A Responsive Mode Parliament}

The EP, much as it has evolved, remains largely a responsive-mode parliament It is not unlike national parliaments in this. The major dissimilarity between the two rests still with how government is chosen : the EU 'government' is not mainly drawn from MEPs. While, unlike national parliaments, the EP sets its own agenda and discusses whatever it likes, this is not the same thing as MEPs having a right of collective or individual legislative initiative. But its potency rises against that of MPs : less than ten per cent of individual MPs' legislative initiatives get transformed into national legislation. The EU's legislative agenda, as set by the Commission and the Council Presidency, curtails the time available for other business. But after the IGC, the Commission significantly cut its output for many reasons (i.e. deceleration following hyper-activity over the Single Market programme, Amsterdam treaty ratification, 1999 financial review, 1999 Euro-elections, work on pre-accession agreements and procedures, and enlargement). There was also a sense that it had completed the framework of legislation for a supranational polity and needed to re-direct its attention to newer items such as immigration and asylum after Amsterdam's ratification. The effect not only occasioned a sense of legislative inertia but posed the question of what would be appropriate roles for the Commission and the EP.

How might the EP's role and powers be refined? What kind and scope of legislation is needed? What does the type of legislation convey about the EU's raison d'être? The controversial nature of much of work surrounding pillar III highlighted the need to define the EU's core values. The EP could properly and publicly act as the EU's conscience and guardian of the values and norms the EU wishes to uphold, perpetuate and defend as hallmarks of the kind of society and polity it is. The EP must insist on openness as a principle of government and advance debate about the parameters and values of good government and civil society in the enlarging EU. This entails reconceptualising and broadening the traditional democratic legitimacy debate.

\section{Re-conceptualising Democratic Legitimacy as a Problem of} Inclusion and Participation

The EU's democratic legitimacy has preoccupied analysts and more recently politicians in the member states. The latter's concern arose largely from anxiety over the presumed level of public disengagement from politics 
and its relatively low level of mobilisation in general, plus disaffection from, and disillusionment with, the EU following the negotiation and ratification of the TEU. The referenda in France, Denmark and Ireland seemed to accentuate the possibility that public disillusionment was such as to compromise the EU's legitimacy. The Irish referendum in June 2001 on enlargement, moreover, confirmed not so much hostility towards integration as passivity towards political processes among the majority and those favourable to the EU. The idea that a minority of voters, on very low turnout in one small member state, might jeopardise integration and enlargement threw into relief arguments about democratic legitimacy and the willingness of the majority of member states to be bound by such an outcome. This represented an important shift in views from the ratification processes surrounding the previous treaty amendments when some governments' cynical manipulation of the referendum and ratification campaigns for domestic party purposes suggested a de-legitimisation of the EU in the public mind. To avert a repeat of this, the Commission and member governments involved groups from across society in the 1996 IGC and ratification of the Treaty of Amsterdam (TEA) and tried to inform the public in as jargon-free way as possible of what was being negotiated, why, when, for whom, and with what result.

Democratic legitimacy can no longer be narrowly seen either in terms of whether or not the EP represents the people, is directly elected by and accountable to it, and exercises legislative powers on its behalf, or purely in institutional terms of rectifying the democratic deficit. Instead it has an instrumental face and a civil orientation. The realisation of a civil society might therefore be a stage in building an ever closer union among the peoples of Europe. This confirms a linkage between rectifying the democratic deficit and promoting ever increasing inclusion. The EP is the best-placed institution to advance this.

Engaging a broader constituency in the process of treaty reform (as, for example happened in the drafting of the Charter on Fundamental Rights) resulted in a more inclusive process. Although the EP was still not accorded the equal status that it sought, transparency, openness and inclusion became more than mere slogans. The EP in an enlarged EU might be their custodian. Therefore, it is possible to re-conceptualise democratic legitimacy as two sides of a euro - having (i)an institutional dimension and (ii) a civil dimension. 


\subsection{Democratic Legitimacy : The Structural Instrumental Institutional Dimension}

The structural instrumental institutional dimension refers to the tradition of construing the democratic deficit and democratic legitimacy in terms of an inappropriate balance of power among the EU's key legislative institutions : the Commission, the Council of Ministers and the EP. Rectifying the imbalance by giving the EP more power was seen as the means to generate democratic legitimacy for the EU more generally. Accordingly, altering the distribution of legislative power among the appointed bodies (the Commission and the Council of Ministers) and the assembly (the EP) designed to represent the people - or the popular sovereign will - was justified in terms of enhancing legislative decisionmakers' democratic accountability, and giving voice to the popular will. The focus was therefore heavily institutional. Any informal or formal increase in EP influence was interpreted as a zero sum decrease in the Council's power and as a reduction in the sovereignty of the member states represented in it.

The tension between the two, enhancing the EP's legislative power and quelling allegations of the EU's undemocratic character (measured against a vague ideal-type representative, liberal democratic standard) preoccupied MEPs and treaty reformers from the 1970s onwards. Arguably, it still conditions responses to advocates of both further reforms to the interinstitutional balance and a 'constitution' for the EU. The Rome Treaty's goal of 'building an ever closer union among the peoples of Europe' remains and 'high political' institution-building type vehicles and economic instruments have been used to advance this. The Nice treaty reforms, though incomplete, confirm this.

Shortly after the first EP elections in 1979 by universal suffrage, MEPs began to appraise the EP's powers and the EC's institutional capacity to realise its goals. Granting the EP more power was justified as a means of reducing the deficit. It also served MEPs' self-interest in making themselves more influential, visible and re-electable. Its greatest drawback lay in the fact that the actual distribution of power among arcane, ill-understood and often vilified EU institutions did not engage public sympathy and interest. Powers subsequently won in the name of the people failed to impress an at best cynical and at worst disinterested and hostile public. This left MEPs fighting in the cold with no real engaged constituency on which they could call. 
While the Single European Act partially shrank the institutional democratic deficit, and while Single Market measures might have been expected to appeal to individuals' pockets, disappointed expectations led to disenchantment. EC institutions' legislative authority expanded and, without adequate national institutional means of monitoring, scrutinising and influencing EU legislative outcomes by MPs, highlighted a growing democratic deficit at national and not simply EU level. It is odd (but probably convenient for national governments) that the wide national level democratic deficit has not received much attention. Referendums on treaty reforms did not shrink the democratic gap: public disaffection grew. However, the EP pushed for greater involvement by both national parliaments at EU level and by political parties. The Nice treaty once again confirms their success in doing so.

\subsection{Democratic Legitimacy : The Civil Dimension}

Individuals' potential participatory role was first assumed by virtue of economic activity (although this too was an exclusive concept of participation because the unemployed were invisible in this sense). Later it was seen largely in terms of political rights - such as the right to contest seats and vote in $\mathrm{EP}$ elections, and then to exercise local electoral rights in an EU state of residence (assuming this was different from one's EU state of origin). Only after this electoral right had been enacted, and only after the Four Freedoms had been enshrined in amendments to the original treaties during the 1980s phase of the Single Market, was an obligation on the part of the EU to protect its citizens' interests abroad deduced and developed under Article 8c. However, it also derived from an exclusive concept of participation. It rested on the possession of the nationality of a member state: EU residents were not afforded the same rights, either in terms of diplomatic and consular protection nor in terms of political and socioeconomic rights. The latter began to assume increasing prominence towards the end of the 1980s. ${ }^{2}$ They were only weakly addressed in the TEU. The Nice Treaty and Charter of Fundamental Rights take them a step further but pressure to incorporate the latter in the next reform or constitution continues to grow. The Charter of Fundamental Rights proclaimed at Nice sets out civil, political, economic and social rights of Eu citizens under six headings: dignity, freedom, equality, solidarity, citizens' rights and justice. These rights are based on the fundamental rights and freedoms recognised by the 
European Convention for the Protection of Human Rights and Fundamental Freedoms and on the constitutional traditions of the member states of the EU.

While EU citizenship remains contested and exclusive, new treaty articles try and safeguard human rights and fundamental liberties and, by introducing principles of inclusion designed to underpin an EU wide civil society and citizenry opened the door to the next logical step in the creation of an ever closer union : an EU level participatory democracy. This builds on the 1973 Danish Presidency's ideas for a 'Human Union', signals EU concern with giving constitutional legitimacy to citizens' roles in the EU (again through the ongoing dynamic of juridical integration which for so long masked the need for greater political and individual engagement to legitimise and uphold integration's goals). It shows that the EU does recognise and is relevant to the daily concerns of the people and addresses issues that matter to them e.g. combating crime, drugs, poverty, unemployment etc. In that sense, the instrumental symbiotic relationship implied by democratic legitimacy becomes concrete: mobilising the public will to validate policies (in the name of the common good) to be implemented by institutions and processes regarded as appropriate and rightful is thereby advanced.

This may be construed, of course, more cynically as a way of promoting or seeking public involvement/awareness for instrumental purposes e.g. to make integration spillover into highly sensitive evolving areas of EU endeavour (notably judicial cooperation and Pillar 2) acceptable in the public mind and possibly therefore acceptable in the mind of some less than enthusiastic law enforcement agencies. However, it corresponds to an agenda recognisable by and relevant to people: Awareness of the EU and the expectation that EU level action is appropriate and desirable has spilt down below the level of educated mobile people, such as students, and the next cohort of recruits to echelons of administrative, business and political elites.

The role of the individual became increasingly prominent as '1992' took off, and the accelerating pace of integration was confirmed. The TEU and TEA (and more recently the Nice treaty reforms) made judicial cooperation and internal security matters affecting individual liberties areas of EU competence and latent arenas for further public disaffection. Two areas of concern voiced at the beginning of the 1980s converged. The 1983 Stuttgart Solemn Declaration on European Union commits the EU members to promoting 'fundamental rights...notably freedom, equality and social 
justice'. This was taken up by the EP's 1984 Draft Treaty establishing the European Union and encapsulated in the later treaty reforms. An important point was confirmed : in expanding the scope of integration via the Single Market legislation, the EC/EU assumed not an exclusive but a concurrent responsibility for developing socio-economic, political and cultural rights of the individual through what might loosely be termed social policy and protection of individuals' fundamental rights. ${ }^{3}$

Although 'Social Europe' was initially a means of augmenting public acceptance of and internalising legitimacy for the Single Market programme, it highlighted inequalities within the member states. 'Inclusion' and 'exclusion' rose up the agenda. Being ill-understood by the public, they did not assuage negativity towards integration nor did the notion of EU citizenship (to be upheld possibly by seeking to guarantee fundamental rights and freedoms - whether derived from the member states' constitutions and the European Convention for the Protection of Human Rights and Fundamental Freedoms, the Social Charter or a new Bill of Rights). However, the idea that individuals could not enjoy rights guaranteed by the treaty by virtue of their socio-economic status, coupled with the need to ensure that any subsequent treaty reforms should not inspire public hostility, helped to shift and broaden understanding of whether and how the EU might be said to enjoy democratic legitimacy.

Once again, the idea that this rested primarily on institutional factors was underscored but also qualified. The debate moved from suggesting that the EU's democratic legitimacy could be reconciled by adhering to the federal notion of it possessing a double legitimacy (entrenched indirectly in the legitimately appointed Council of Ministers and directly in the elected EP). ${ }^{4}$ The emphasis switched to the requirement that effectiveness and democracy be reconciled : binding acts need to be subject to political control and participation in order to be accepted as legitimate. ${ }^{5}$ The idea that the EU institutions exercised power in an authoritative, rightful, just and democratic way was re-asserted. It was qualified, however, by recognition that people had to see and believe that decisions were just and based on the rule of law, that they were not arbitrary but corresponded to an agenda that was directly relevant to them and which responded to their needs. The goal of improving the EU's image and making it relevant to and comprehensible by the people was taken up in the Commission whose own democratic legitimacy was also disputed. ${ }^{6}$ This implied that the traditional view of seeing a relationship between democratic legitimacy and political engagement had been 
broadened. No longer was it assumed that propensity to vote in EP elections was simply contingent upon information levels and favourability towards the $\mathrm{EU}$; that the more 'educated' voters were, the more likely they would use their vote and so increase turnout and (using this as an indicator of legitimacy) boost the EP's democratic legitimacy; and that a low turnout inevitably meant that the institutions were insufficiently legitimate. ${ }^{7}$ Instead, there was growing awareness that the propensity to vote was but one part of the democratic legitimacy jigsaw. Opinion trends in favourability towards the EU provided a very crude indicator of attitudes towards the EU but hid factors which possibly explained whether the EU was regarded as democratically legitimate or not.

\section{Normative Issues : Beyond the deficit}

Had institutional reform been the means of enhancing democratic legitimacy, public acceptance of and satisfaction with the EU should have risen significantly. The EP had been periodically elected, and its legislative control and supervisory powers vis-à-vis the Commission and Council had been enhanced. Yet, the EU was still seen as insufficiently democratic. Rectifying the democratic deficit by institutional means was itself a partial and somewhat defective response. Shrinking the democratic deficit demanded attention to the neglected issue of the relationship between public engagement and public perceptions of the just, lawful and rightful exercise of power by government institutions in a supranational setting. This was also too narrowly conceived in institutional terms. New institutions and improved inter-institutional interaction and communication were advocated and devised. They are a necessary, vital but insufficient feature of rectifying the deficit and enhancing democratic legitimacy. Why?

Institutional processes and outcomes that seem distant and irrelevant to individuals' daily concerns fail to engage public attention, interest or respect. Lack of respect further erodes public acceptance of embryonic democratic institutions (notably the EP) struggling to establish their legitimacy and credentials in the minds both of elites and the public. The difficulty is exacerbated when the national political elites themselves contest that legitimacy publicly and frequently imply that especially the EP (purporting to have been elected by and to represent the people) and the Commission (portrayed as a faceless, arrogant, technocracy) are incompetent. That message in turn implies that they cannot be trusted to exercise power and allocate resources in a way which may be seen as rightful, just, appropriate 
and legitimate. It is not surprising that publics should then be disinclined to hold those institutions in any esteem, identify in any way with what might loosely be termed 'their mission', let alone accept them. Apparent dissimilarity from national institutions of government further aggravates the problem.

However, at the same time, publics across the EU did not universally share a view that the EU's key institutions operated wholly irresponsibly and illegitimately. Ignorance of the processes and national governments' tendency to claim points for EU achievements masked positive supranational realities for a long time. Only when the issue of the future of European integration became a part of the daily political discourse of member governments and they gave it a high public profile continuously - rather than sporadically on the occasion of European elections - did the general public's awareness grow and anxiety come to be voiced more effectively about the nature of democratic practice in the EC/EU.

\subsection{Normative Issues and Democratic Legitimacy}

Distinguishing between the rhetoric of democracy and defining it in terms of political liberalism and plurality for external purposes propelled EU transformation. EU elites and governments moved from the traditional method of treaty reforms by diplomatic bargaining or 'gradual accretion"8, conducted largely in secret among themselves, to initially a more widely based semi-public deliberation on treaty reform. When national governments had publicly to justify themselves - and especially their reasons for choosing the Santer Commission when it resigned, and its successor - the debate widened. Political elites wanted to appear responsive to citizens' interests, such as 'green', race and welfare issues.' Democratic enhancement was pursued internally by reforming institutional practice to shake-up and rebalance inter-institutional power, and externally by defining and prioritising an appropriate and relevant public policy agenda by people enjoying the public support of the national governments and the EP. Contemporary views on democratic legitimacy seek to transcend the traditional allocation and territorial division of powers based on constitutional models and functional capacity in favour of including increasing sections of society. The process by which the Charter of Fundamental Rights was elaborated and the more recent e-interaction with the Commission reflect this. 
Similarly, in constructing a new 'European architecture' at the end of the 1980 s, the issue arose of defining the kind of liberal democracy the EU claimed to be. What values and norms did it espouse and expect applicant states to uphold? Why refine and state them in the TEU? Why, by the time of the IGCs had the EU been encouraged to express itself against racism and xenophobia? Why, in short, had the question of the EU's political culture emerged when only a few years earlier, political ideology had seemed relatively unimportant? It had not even served usefully to differentiate many of the EP's party groups, much less their component national parties, from one another. European integration had spilled over into what might loosely be called political philosophy as pressure grew for effective scrutiny, control and redress against the abuse of legislative, administrative and regulatory acts. ${ }^{9}$ The language of European integration also seemed to become a more pervasive part of domestic political discourse and pointed to an incipient and almost imperceptible change in and Europeanisation of domestic political cultures.

Apart from the demands of Euro-elections and effective action within the EP, two key impulses were (i), the pressure for an EU Ombudsman and EU Bill of Rights or EU accession to the European Convention on Human Rights; and (ii) enlargement to states emerging from totalitarianism that did not fully appreciate the socio-economic and political obligations and requirements membership implied. They seemed to think the former could be alleviated by resource transfers from the EU to them; that economic change and growth would induce political stability, and that political stability would enhance economic prosperity. They did not appreciate what the acquis communautaire meant in practice in terms, for example, of the immediate demands of participating effectively in the EU decisionmaking structures with all that implied for respect for the rule of law, political behaviour and democratic engagement. ${ }^{10}$ Some highly delicate and contentious issues needed to be broached simultaneously with the EU's own expanding agenda for further political integration, institutional reform guided by openness and transparency, judicial cooperation, the common foreign and security policy (CFSP) and movement towards a common defence.

The EU internally had to confront the tension between its self-image as a civilian-power on the world stage at a time when it was being called on to deploy military resources in war zones irrespective of the rudimentary state of the CFSP. Yet, the logic of transparency and openness queried the way 
in which individual states gave their own citizens access to information on public policy. ${ }^{11}$ The EU needed some approximation of rules on this for its own citizens just as less than democratic and open states sought EU accession. The confluence of the debate over the internal reform of the EU and impending enlargement underlined a number of normative assumptions at the heart of the EU's belief system. In particular, EU member governments' interpretation of democracy and democratic practice reflected a number of principles and norms which were to be outlined in the TEU as fundamental elements of the EU's being. The notions of fairness, openness, equality, democratic practice, respect for human rights and the rule of law were underscored. They were seen as relevant to the kind of civil society the EU purportedly promoted, and to the EU's institutions' composition and internal organisation - both at the crux of the deliberations about the EU's enlargement when, to whom, how and under what rules and conditions. Again, the internal relevance of these notions was tested with reference to existing institutional peculiarities.

In particular, the ratio of population to number of seats or posts held by nationals of each member state posed proved so intractable at the IGC that decisions were postponed. Reconciling the imperative of ensuring that the EU's institutions are able to function as effectively, efficiently, openly, responsibly and democratically as possible with the desire of each member state (and applicant) to ensure that they have individual representation in key institutions such as the Commission requires a major reappraisal of the concept and purpose of national representation in each institution. It does not necessarily follow that the principles of democratic legitimacy, equality and fairness are best met either by allowing each state at least one seat/post by letting Luxembourg's disproportionately large representation guide small applicant states' representation if by applying that ratio the effectiveness, efficiency and capacity of the EU institutions to fulfil their roles and obligations are thereby compromised. Widespread elite and public dissatisfaction could follow and imperil the democratic legitimacy of the EU and endanger its survival. That unintended effect would not serve any state's interest. We must, therefore, go beyond the narrow concept of democratic legitimacy and its institutional confines to distil a contemporary meaning that would both satisfy the legitimate desire to practise democratic values at all levels and the instrumental goal of promoting contentious but essential institutional reforms to accommodate a large number of member states - a number for whom the original institutions were not conceived. 


\subsection{From Norms to practice - Democratic Legitimacy and Inclusion- towards a participatory polity?}

During the 1950s and early 1960s, functionalists and neo-functionalists argued that a switch in grass-roots and elite loyalties from national to supranational settings would follow from the latter more adequately satisfying socio-economic needs than the former. ${ }^{12}$ An instrumental relationship was presumed to exist. It rested on the assumption that the EC would be ever-more prosperous and always able to deliver economic goods whereas national governments would not. The dilemma remains : the legitimacy of national government itself, rests on its capacity to deliver sufficient economic public goods. ${ }^{13}$ Accordingly, excessive expectations held in many would-be EU states of the EU's capacity to deliver economic goods within a very short time-frame might be expected to jeopardise the EU's legitimacy. Should one EP enlargement task be to address that? Is it especially critical given that defining the who, what, when, how and meaning of 'Europe' coincides with a time of increasing immigration from the border areas and beyond of the 'new Europe'? Some argue that progress is easier when passive acquiescence to decisions can be assumed, as Lindberg suggested years ago, and their legitimacy accepted by default. Accordingly, attempts to augment public awareness of who takes decisions in the EU, why, when and for what purpose and with what result are misplaced because people are primarily interested in parochial, local domestic and socio-economic matters not in what the EU does or does not do. Thus, local problems should be addressed locally; and EU level 'intervention' (under the conditions of appropriateness and subsidiarity) should be strictly limited. As Wessels shows, national factors constrain the development of a European political order.

Rectifying the supranational deficit highlighted national level deficiencies in control over executives and helped to codify in the TEA national parliaments' participation in scrutinising and even influencing EU policymaking. The democratic deficit ceased to be seen in purely supranational terms. Combined with the focus on inclusion and exclusion, action to combat racism and operationalising EU citizenship, and accelerating deepening and politicisation of the EU, highlighted the fact that the excluded or self-marginalised are often the least able to participate as politically engaged citizens. If the EU is able to combat exclusion in any small way, the wider community might be better disposed to internalising its 
legitimacy : the EP's 1990 proposals on the EU's constitutional basis reflected such pragmatic but inclusive criteria of EU citizenship. ${ }^{14}$

It may be argued that if legitimacy can be inferred from public acquiescence, enhancing participation is unnecessary : elites should act in the common European good, which, in turn, should be defined in terms of promoting sustainable economic development. But if it is argued enhancing public participation in decisionmaking about public policy and public goods is the appropriate means of securing democratic legitimacy for government, further institutional reform should ensue guided by the spirit of enhancing democratic practice, efficiency and transparency : EU governance via elites and bureaucratic hierarchies should cede place to networks communicating their own expertise to public policymakers. Even then, democratic legitimacy will not be enhanced unless such organisations sustain their engagement and believe that they are heard: responsiveness, accountability, fairness and openness must remain EU leitmotifs.

\subsection{Reconciling the Tension between Passive Acquiescence and an Engaged Civil Society}

Traditionally tension between passive acquiescence and an engaged civil society has been subsumed in the debate between the functionalists and neofunctionalists on the one hand and federalists on the other. Crudely speaking, the latter are associated with the idea of a politically engaged citizenry partly because their overriding interest has been with the creation of an integrated Europe based on a federal, liberal democratic constitution. Parliamentary democracy in shape and practice has been more important than functional representation of economically active interest groups, elites and employees. ${ }^{15}$ However, democracy is more than a set of procedures and guiding principles: it is also the pursuit of democratic values involving the extension of popular participation in the political process. ${ }^{16}$ Therefore, the politicisation of a decision-making and legislative procedure once held to be largely technocratic has implications for the conduct of supranational government both among its institutional arms and vis-à-vis its citizenry. A symbiotic relationship is thereby implied between EU institutions which are separate from the EU's emergent civil society but central to developing and sustaining a democratic political order. Democracy may be 'concerned, on the one hand, with the re-form of state power and, on the other, with the restructuring of civil society'. ${ }^{17}$ 
Perhaps the problem lies more in the perceived need to give the public the impression of it being able to exercise (even indirectly via MPs and MEPs) some influence over binding public policy decisions taken by governments than in the reality. In practice, the more likely it is that effective solutions require EU level (or even international) action, the less likely it will be that effective democratic participation and control by the people will be feasible. It would be fool-hardy to infer that EU decisionmakers do not therefore require a democratic mandate and be seen to be democratically accountable to the people. The EP must act as 'champion of the people'. Paradoxically, by facilitating a more participatory citizenry, the EU may stimulate greater interest in (and possibly opposition to) its agenda while simultaneously boosting its democratic legitimacy. The resulting reduction in the democratic deficit and enhancement of legitimacy would therefore reflect the idea that citizens had (and saw themselves as able to exercise) a just and rightful share in the process of supranational policymaking and 'government', possibly via local democratic mechanisms, such as a regional assembly, linked to higher levels. ${ }^{18}$ Sub-national units, by fostering participation may help bring the EU closer to the citizen, define a European identity, cultural and social cohesion (particularly if the definition of citizenship were refined to include fundamental values - social, environmental and cultural), and enhance democratic practice. ${ }^{19}$ The articulation of opposition to political proposals, the chance to alter priorities through open, reasoned argument, the need to accommodate dissent without stultifying progress, and the desirability of promoting engaged political argument are all things that the EP is ideally placed to do. These functions need to be performed openly and be clearly linked to ultimate political choices confirmed by the majority in both the EP and the Council of Ministers. Peaceful accommodation and resolution of dissent and constructive steps to mediating and facilitating argument are essential and desirable components of the construction of the EU polity.

Supranational democracy, therefore, might be seen as a dynamic process mediated by multi-level networks ${ }^{20}$ embracing several variants of democracy. These include: direct and participatory democracy (derived from the ancient Athenian model where citizens directly engage in public policymaking); liberal, representative democracy (where citizens' interests are represented and articulated within the framework of the rule of law) ; deliberative democracy (where it behoves democratic institutions to resolve conflicts over political preferences) ${ }^{21}$; supplemented perhaps by constitutionalism $^{22}$ and associational democracy (which prioritises freedom and argues that its effective pursuit rests on individuals working together). ${ }^{23}$ 
The EU must work out how to maximise sufficient public engagement without compromising open, efficient, democratically accountable government.

This presents an interesting conceptual dilemma. It may be that optimal participation exists when policy communities normally associated with maintaining the system engage the expertise of epistemic communities and advocacy communities ${ }^{24}$ and themselves adapt to permit wider participation. In the context of EU enlargement, this has implications for politicoeconomic, social and technocratic-bureaucratic elite communities, networks and interactions. Questioning the acceptability of such a widening may imperil how legitimate they are perceived to be and so widen divisions between included and excluded communities, however conceived.

Applicant states' ability to behave politically in a liberal democratic manner with all that existing member states usually understand in terms of respect for the rule of law, justice, equality and liberty cannot be taken to mean that they comprehend, wish to uphold, value, share and will follow EU practice. The EU decided that a test of fitness would be their institutional and administrative capacity to implement the acquis. ${ }^{25}$ In a transformative phase, EU's players need to explain procedures, practices and processes and underlying normative beliefs and value system. The EP should fully exploit its implied socialisation role in this respect ${ }^{26}$

\section{Defining and Maintaining a European Democracy: an enlargement role for the EP?}

The EP remains in search of a role. In the past, this search primarily focused on acquiring legislative authority and building a polity with appropriate built-in checks and balances. Theoretically, it is well-placed to act as a voice and champion of the people and to effectively scrutinise the executive and the legislative process. In practice, internal organisational constraints inhibit it from performing as independent, supranational role as might be desirable. Enlargement, with more MEPs and political groups, must not dilute its ability to sustain its credibility as a competent, responsive and responsible legislature able to effect the democratic accountability of the 'government' in an open, just and acceptable manner. It must develop and sustain effective channels of communication internally within and among its own parties, Commission and Council; and externally with national and subnational elected bodies, notably parliaments and assemblies. To project a 
credible public persona, it must improve its relationship with the EU and public. Herein lies the democratic deficit paradox. Paradoxically, the deficit grew with each step taken to reduce EP weakness in effecting control over the Council and the Commission, and with each increase in its visibility. It now has a public, human face. It must now foster genuine participation and public engagement in a political process which might be novel at EU level and less than rivetting in the national setting. The EP's political groups as well as national parliaments' political parties have to contribute to this.

\subsection{The EP : in Perpetual Search of a Role?}

How the EP evolves and the principles and values it practises in the name of liberal representative democratic government will inform any role it secures in contributing to further treaty revision and the next IGC in 2002. It must genuinely influence the EU's legislative agenda and so entrench a wider, traditional parliamentary role for itself in evolving, transforming, redefining and sustaining that system. The transformative role is arguably the more challenging, interesting and potent for the post-Nice period and run-up to the next IGC.

The EP remains a supremely constitutional player . The EP signalled to both the public, but also crucially, the member governments what it perceived to be key elements of democratic practice when it finally persuaded the Santer Commission to resign in March 1999. Since the EP's inception it had been argued that: the power to censure and force the resignation of the Commission en bloc was too nuclear a weapon to be used; that governments could theoretically reinstate the censured Commission (or most of its original membership); that the EP would probably never muster the requisite two-thirds majority to pass a censure motion; and that censuring the Commission would be merely symbolic - hitting the Commission rather than the real target - member governments and Council. The logistical obstacles were seen to be overwhelming. However, when the EP finally edged the Commission out, it achieved many things simultaneously and arguably established, for itself, a millennium role which had hitherto proved elusive. As custodian of the principles and practice of good government, it routed practices inimical to them. It established the need for a Commission capable of leading and enjoying EP support, not merely EP confidence. But does the EP enjoy public confidence? Mobilising high election turnout at the next Euro-election may be one such indicator when it has the chance to rehearse its new role : to transform EU governance in line with accepted, if 
sometimes unarticulated, values and norms. These might embrace the following derived from a more nuanced interpretation of its existing legislative, budgetary and control functions. Accordingly, the EP should:

act as the custodian, guardian and transmitter of the supranational polity's normative beliefs, practices and values (to be upheld by EU political classes)

promote the development of a EU participatory civil society and political culture derived from western liberal democracy

act as the voice and champion of the people - responsible and responsive

communicate and educate - keep people informed and seek to be kept informed by others

Custodian and guardian of normative beliefs and values. The EP should complement the Commission's 'guardian of the treaty' role designed to ensure compliance with EU law. It should act as a check against the abuse of values, practices, norms and political behaviour (by EU institutions) which compromise western liberal democratic values.

Advocate of the development of a EU participatory civil society. In promoting a participatory and engaged supranational democracy and civil society, the EP could reform its own working methods to enhance the opportunity for mutually beneficial consultation with national parliamentary committees, the Committee of the Regions, and other democratically organised transnational groups and political parties.

Communication and education. The EP should help to sustain and develop an open, participatory, democratic political culture by acting as a conduit for the transmission of information both among its own members, horizontally with other EU institutions, and vertically with national and regional bodies and political parties. This would reinforce effective legislative and control functions. In defining the agenda, the EP might accordingly stress appropriate use of information technology for civil society

Voice of the people. The EP must continue to act as the voice of the people, ensuring that it is responsive, accountable and responsible in its advocacy of EU level action, and worthy of public trust.

The foregoing implies that the EP will be a visible, intelligible and accessible forum in the future. The public needs reassuring over the purpose, rightfulness and scope of integration. Anxiety over potential abuse of power by EU (and national) level bodies - whether the Commission or national 
governments and their agents has to be assuaged. Arguments about an appropriate division of power remain but one element in the construction of appropriate institutions for the EU. Traditional concerns about the conduct of democratic politics cannot be abandoned. They must be affirmed, articulated, advocated and practised. While IT facilitates greater participation in $e$ government policy discussion groups and networks, it does not eliminate the need for appropriate institutions to safeguard values and practices upon which liberal democratic government at all levels is founded. The EP must address this element of the debate about the appropriate organisational form that participatory, democratic government might take.

The run-up to the next IGC and waves of enlargement are times when the traditions of west European liberal democratic practice should be applauded and refined in pursuit of inclusiveness: acceptance of them is an essential and necessary precondition both of EU membership and of the EU being able to act effectively, openly, accountably, responsibly and credibly. The overall implication is that the EP retains multiple roles. They need reprioritising to address the requirements of building an effective, credible, open, democratic supranational polity. Crucial is the EP's contribution to constructing a constitution for the wider Europe. The EP, if it performs the roles listed above, will be in an unparalleled position to distil the values which should guide and underpin the ever closer union of the EU as it enlarges.

\section{Endnotes}

1 J Lodge (ed.) The 1999 Elections to the European Parliament, (New York:: Palgrave, 2001).

2 D O'Keeffe, "Union citizenship' in Legal lssues of the Maastricht Treaty ed. D O'Keeffe and P Twomey (London: Chancery Press,1995) 97-94; and C Closa, 
'Citizenship of the Union and Nationality of Member States', Common Market Law Review, 32 (1995) 487-518.

${ }^{3}$ (Collins, 90$)$.

4 C. Stephanou, Reformes et Mutations de l'Union Européenne, (Bruxelles: Bruylant, 1997.)

5 W Wessels, "The modern European state and the European Union: Democratic erosion or a new kind of polity?' in S Andersen and K Eliassen (ed.s) The European Union: How Democratic is it? (London: Sage,1996) 57 - 70, 58.

${ }^{6} \mathrm{~J}$ Gerkrath, 'La critique de la légitimité democratique de l'Union européenne selon la Cour constitutionnelle federale de Karlsruhe", in G Duprat (ed.) L'Union européenne, droit, politique, democratie, (Paris : Presses Universitaires de France, 1996), 209-242, 230.

7 J Lodge, The European Parliament in S Andersen and $\mathrm{K}$ Eliassen eds., The European Union: How Democratic is it? , (London: Sage, 1996), 187-214.

${ }^{8}$ R. Pryce (ed) The Dynamics of European Union, (Beckenham: Croom Helm, 1987).

${ }^{9} \mathrm{~J}-\mathrm{M}$ Ferry and P Thibaud, Discussion sur l'Europe, (Paris: Calmann-Levy, 1992)

${ }^{10}$ European Commission, Agenda 2000:For a stronger and wider Union, Bulletin of the EU, Supplement 5/1997, Luxembourg.

${ }^{11}$ J Lodge, 'Transparency and Democratic Legitimacy', Journal of Common Market Studies, 32 , 1994

12 Taylor, 125

13 Wessels, 1996: 57

${ }^{14} \mathrm{EP}, 1993: 55$

${ }^{15} \mathrm{~S}$ Andersen and K Eliassen (eds) The European Union: How Democratic is it?, (London: Sage,1996).

${ }^{16}$ D. Archibugi \& D Held (eds) Cosmopolitan Democracy, (Oxford: Polity,1995).

${ }^{17}$ D. Held, Models of Democracy (2nd ed) (Oxford: Polity, 1996), 316. 
${ }^{18}$ D Martin, Europe: An Ever Closer Union?, (Nottingham: Spokesman, 1991), 18.

${ }^{19}$ European Commission (1997a) Actes du Colloque des Chaires Jean Monnet sur la Conference intergouvernementale de 1996, Brussels 6-7 May,1996, 297.

20 C Ansell, C.Parsons \& K Darden "Dual networks in European regional Development Policy", Journal of Cornmon Market Studies, 35, no.3 (1977): 347376,347

${ }^{21}$ See, D Miller, "Deliberative Democracy and Social Choice", in D Held (ed.) Prospects for Democracy (Oxford: Polity, 1993) 74-92, 75.

$22 \mathrm{~J} \mathrm{H}$ H Weiler, "The Reformation of European Constitutionalism", Journal of Common Market Studies, 35 no.1, 1997, 97-131.

${ }^{23}$ P Hirst, "Associational Democracy", in Prospects for Democracy D Held (ed.) (Oxford: Polity, 1993), 112-135, 112 and 132.

24 P A Sabatier \& H C Jenkins-Smith (ed.s) Policy Change and Learning : An Advocacy Coalition Approach, (Boulder: Westview Press), 1993; G Dudley \& J Richardson, "Why does policy change over time? Adversarial policy communities, alternative policy arenas, and British trunk roads policy 1945-95", Journal of European Public Policy, 3, 1996, 63-83; and Sabatier, 1988:140.

${ }^{25}$ Agenda 2000:84

${ }^{26}$ See Bailer and Schneider. 